\title{
Synonymy of Pseudomonas gladioli Severini 1913 and Pseudomonas marginata (McCulloch 1921) Stapp 1928
}

\author{
D. C. HILDEBRAND, N. J. PALLERONI, and M. DOUDOROFF \\ University of California, Berkeley, California 94720
}

\begin{abstract}
An appraisal of the relationship of Pseudomonas gladioli Severini 1913 and Pseudomonas marginata (McCulloch 1921) Stapp 1928 has been conducted on the basis of an examination of the properties of these species as described in the literature and of the properties of the "lectotype" strain of $P$. marginata. Examination of this strain (ATCC 10248), which was deposited in the ATCC by McCulloch under the name Pseudomonas marginata, indicates that the previous descriptions of $P$. marginata were incorrect in several instances, such as in capsule formation and fluorescence of the yellow pigment it produces. Because the corrected description of $P$. marginata is identical to the original description of $P$. gladioli, the two names are regarded as synonyms, with $P$. gladioli having priority. Strain ATCC 10248 (NCPPB 1891) is designated as the neotype strain of $P$. gladioli.
\end{abstract}

Two species of phytopathogenic pseudomonads which cause disease of Gladiolus sp. have been carried in the literature under the names Pseudomonas gladioli and Pseudomonas marginata. The first of these was described in 1913 by Severini (15) as causing a rot of gladiolus corms. The second, described by McCulloch in 1921 (11) as Bacterium marginatum, caused a spot and basal rot of leaves of Gladiolus sp.

Studies of $P$. marginata have indicated that there is confusion regarding the production of a fluorescent pigment by this organism. Both pigment production (5) and lack of pigment production $(1,19)$ have been noted. This confusion in the description of $P$. marginata and its apparent similarity to $P$. gladioli with regard to hosts attacked and symptoms elicited suggested that a reappraisal should be made of the relationship of these two organisms.

\section{MATERIALS AND METHODS}

Bacterial strain. The "lectotype" strain of $P$. marginata, McCulloch's strain Col. 3, was obtained from M. P. Starr (PM 107). It was deposited by McCulloch in the American Type Culture Collection, Rockville, Md., as ATCC 10248 and is held by the National Collection of Plant Pathogenic Bacteria, Harpenden, England, as NCPPB 1891. To our knowledge, none of Severini's original strains of $P$. gladioli are extant, and Severini's original description (15) of $P$. gladioli thus serves as the nomenclatural type until a neotype is designated (see below).

Methods. The methods used to characterize strain Col. 3 have been described previously (17).

\section{RESULTS}

Description comparison. It is evident that few differences distinguish these two phytopathogens (Table 1). They are alike in size, flagellation, nitrate reduction, and gelatin liquefaction. From the literature, the principal differences appear to be in the possession of capsules by $P$. marginata and pigment production by $P$. gladioli. Severini (15) described $P$. gladioli as producing "a diffusible pale yellow pigment which now and then tended to become orange, and depending upon the substrate becoming reddish." Pigment production was not reported by McCulloch (11) in the original description of $P$. marginata. In 1924, however, she (12) published a more extensive study of this species in which she stated that a faint trace of green appeared in some cultures after 8 weeks of incubation in Uschinsky's solution and that Fermi's solution became pale yellowish after 3 to 4 weeks; in Cohn's solution, the sediment became yellow, and in one set of 
TABLE 1. Properties of Pseudomonas gladioli and P. marginata

\begin{tabular}{|c|c|c|}
\hline Properties & P. gladioli & P. marginata \\
\hline Gram stain & $-{ }^{a}$ & - \\
\hline Spore formation & - & - \\
\hline Oxygen requirement & + & + \\
\hline Gelatin liquefaction & + & + \\
\hline Pectolytic enzymes & $+(11)$ & $+(9)$ \\
\hline Nitrate reduction & - & - \\
\hline Capsules & - & + \\
\hline Indole formation & - & \pm \\
\hline Size & 0.6 by 2.3 to $2.8 \mu \mathrm{m}$ & $\begin{array}{l}0.5 \text { to } 0.8 \text { by } 0.8 \text { to } 3.4 \mu \mathrm{m} ; 0.5 \text { to } 0.6 \text { by } \\
0.8 \text { to } 1.8 \mu \mathrm{m} \text { and occasionally longer }(12) \text {. }\end{array}$ \\
\hline Flagella & One or more bipolar, 3 to $8 \mu \mathrm{m}$ long. & $\begin{array}{l}\text { One to two polar; one to four bipolar, } \\
3 \text { to } 8 \mu \mathrm{m} \text { long (12). }\end{array}$ \\
\hline Pigments & $\begin{array}{l}\text { Diffusible pale yellow, occasional } \\
\text { orange, and with certain } \\
\text { substrates reddish. }\end{array}$ & $\begin{array}{l}\text { None reported; Fermi's medium becomes pale } \\
\text { yellowish-green, sediment in Cohn's medium } \\
\text { yellowish and occasionally orange yellow } \\
\text { (12); fluorescent green (6); brown (13); } \\
\text { nonfluorescent yellowish-green (R. W. Ballard, } \\
\text { Ph.D. thesis). }\end{array}$ \\
\hline Disease symptoms & $\begin{array}{l}\text { Corm and basal leaf rot of Gladiolus } \\
\text { sp., yellow-brown exudate when } \\
\text { squeezed. }\end{array}$ & $\begin{array}{l}\text { Leaf spot and rot of Gladiolus sp.; } \\
\text { spot and basal rot of leaves of Gladiolus } \\
\text { sp., corm scab from which a copious gummy } \\
\text { exudate occurs (12). }\end{array}$ \\
\hline
\end{tabular}

${ }^{a}$ Unless otherwise noted, the descriptions are taken from Severini (15) and McCulloch (11) for $P$. gladioli and P. marginata, respectively.

cultures, the color was orange-yellow. These properties were not included in the technical description of the pathogen presented in the 1924 paper, and consequently they did not appear in later publications by other authors (3, $6,8,18,19)$.

Bryan (5) reported in 1927 that a green fluorescent pigment was produced in certain media by $P$. marginata. This report apparently is the basis for the later descriptions $(2,4,8$, 18 ) of $P$. marginata as producing a green fluorescent pigment. However, it appears that this report of the production of a fluorescent pigment is in error. Starr and Burkholder (20) stated that $P$. marginata had never been known to produce a green-fluorescent diffusible pigment, although they do not mention Bryan's observation. Later, it was noted by $\mathrm{R}$. W. Ballard (Ph.D. thesis, Univ. of California, Berkeley, 1969) that strains of $P$. marginata, including two strains derived from McCulloch's collection (NCPPB 1890 and 1981), formed a nonfluorescent, yellowish-green pigment in an iron-deficient medium such as King's B medium (10). This has been noted by us as well. This yellow pigment has the same appearance in sunlight as that formed by fluorescent pseudomonads and consequently could have been confused with the fluorescent pigment by Bryan (5). We now know that the production of fluorescent diffusible pigments is easily recognized by observation under an ultraviolet source of low wave length, and this important technical detail is never mentioned by early workers in this field.

Reddish pigments have not been reported for $P$. marginata. However, Severini (15) indicated that this occurred only on certain unstated substrates. One of the media described by him was a decoction prepared from gladiolus tissue. A similar medium was prepared by us and tested as a substrate for pigment formation. This medium initially had a slight reddish cast. The color remained unchanged in control tubes but became more intense in tubes inoculated with $P$. marginata strains and was especially pronounced when viewed in direct sunlight. Several strains of $P$. marginata, including strain NCPPB 1891, formed a more intense reddish color than other strains. Reddish colors also have been noted on other occasions. The margins of $P$. marginata colonies occasionally turned a pinkish color when the organisms were grown on a polypectate gel medium (medium C) used to detect pectolytic enzymes (9). Furthermore, it should be noted that strains of 
$P$. alliicola, an organism considered to be identical to $P$. marginata by Ballard et al. (1), produce brown pigments in culture. This pigment occasionally appears reddish during early stages of formation. A brown pigment has also been reported for $P$. marginata (13).

Symptom comparison. The question of similarity or differences in phytopathogenic symptoms should also be considered. $P$. gladioli was described as causing a rot of gladiolus corms. These symptoms were at first manifested as yellow or reddish sunken spots on the corm. The corm later became flaccid, and a yellow-brown mass could be squeezed out of it. Lesions were described as occurring on the basal portion of the leaves in addition to the corms. In severe cases, the plants break over at the base. McCulloch's first report of $P$. marginata (11) provided a somewhat similar description. Lesions were reported to occur occasionally on all parts of leaves but were most often confined to the basal portions. Under warm and moist conditions, rot spread rapidly and deeply into tissues, causing the collapse of the aerial part of the plant. Her later report (12) also described these symptoms. In addition, lesions were reported on the corm which were termed scab. These corm lesions exudea a gummy suostance. Her attempts to produce rot in mature corms through wound inoculations were unsuccessful, although it was indicated that rot could be caused in immature corms under conditions of high moisture.

Properties of P. marginata ATCC 10248 (NCPPB 1891). The properties of $P$. marginata ATCC 10248 agree with those originally given for P. gladioli as follows: cells are gram-negative; endospores and capsules are not produced; cells are aerobic; gelatin is liquefied; pectolytic enzymes are produced; nitrate is not reduced; indole is not produced after 24,48 , or $96 \mathrm{~h}$; one to four polar flagella are present (Fig. 1); size ranges from 0.7 to 0.8 by 2.3 to $2.8 \mu \mathrm{m}$ (Fig. 2); and pigment formation is described as being diffusible, nonfluorescent pale yellow to yellowish-green with rarely a reddish pigment, depending upon the medium.

Additional properties of $P$. marginata strain ATCC 10248 as determined by Ballard et al. (1) reveal that poly- $\beta$-hydroxybutyric acid is accumulated but is not hydrolyzed; growth occurs at $41 \mathrm{C}$ but not $4 \mathrm{C}$; it is oxidase positive and arginine dihydrolase negative; and starch is not hydrolyzed. Organic substrates utilized as sole sources of carbon and energy include: D-ribose, $\mathrm{D}$-xylose, $\mathrm{D}$-arabinose, $\mathrm{L}$-arabinose, D-fucose, D-glucose, D-mannose, D-galactose, D-fructose, sucrose, trehalose, cellobiose, gluconate, 2-ketogluconate, saccharate, mucate, salicin, acetate, propionate, butyrate, isobutyrate, valerate, heptanoate, caprylate, caprate, caproate, pelargonate, malonate, succinate, fumarate, glutarate, adipate, azelate, sebacate, D-malate, L-malate, D-(-)-tartrate, mesotartrate, DL- $\beta$-hydroxybutyrate, DL-lactate, glycerate, hydroxymethylglutarate, citrate, $\alpha$-ketoglutarate, pyruvate, aconitate, citraconate, mesaconate, adonitol, mannitol, sorbitol, meso-inositol, glycerol, ethanol, $n$-propanol, $n$-butanol, benzoate, $p$-hydroxybenzoate, phenylacetate, quinate, glycine, D-alanine, Lalanine, $\beta$-alanine, $\mathrm{L}$-serine, $\mathrm{L}$-threonine, Lleucine, $\mathrm{L}$-isoleucine, valine, L-aspartate, Lglutamate, L-lysine, DL-arginine, DL-ornithine, DL-citrilline, DL- $\alpha$-aminobutyrate, $\gamma$-aminobutyrate, $\mathrm{L}$-histidine, kynurenate, anthranilate, ethanolamine, betaine, sacrosine, hippurate, nicotinate, and trigonelline; but not maltose,
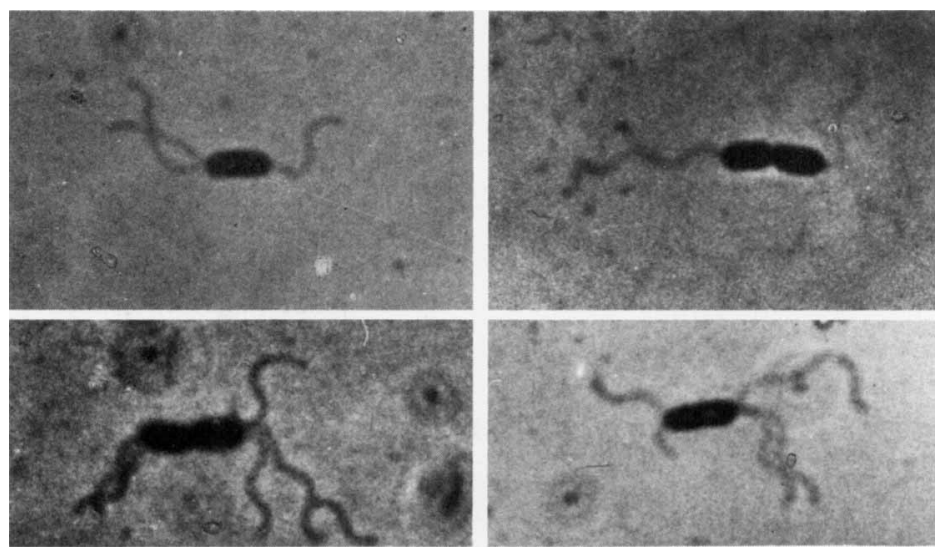

FIG. 1. Polar flagellated cells of Pseudomonas gladioli ATCC 10248 stained by Leifson's method. (X 1,200) 


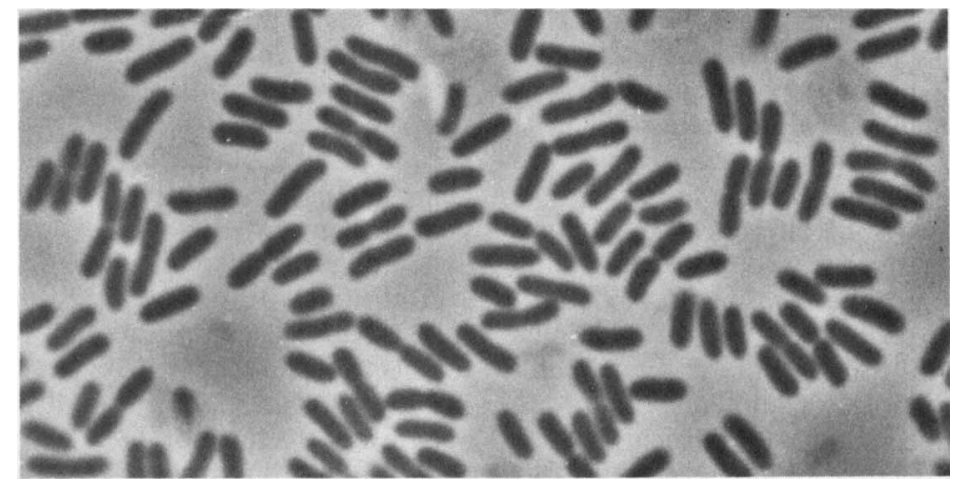

Fig. 2. Cells of Pseudomonas gladioli ATCC 10248 grown in a mineral base plus $0.5 \%$ yeast extract and $0.2 \%$ lactate, observed under phase contrast. $(\times 1,200)$

lactose, L-rhamnose, starch, inulin, isovalerate, maleate, pimelate, suberate, glycollate, poly- $\beta$ hydroxybutyrate, levulinate, itaconate, erythritol, ethyleneglycol, propyleneglycol, 2,3butyleneglycol, isopropanol, isobutanol, geraniol, D-mandelate, L-mandelate, benzoyl formate, o-hydroxybenzoate, phthalate, phenylethanediol, $m$-hydroxybenzoate, phenol, testosterone, naphthalene, DL-norleucine, $\mathrm{DL}-\alpha$-aminovalerate, $\delta$-aminovalerate, $\mathrm{D}$-tryptophan, benzylamine, putrescine, spermine, histamine, tryptamine, $\alpha$-amylamine, butylamine, creatine, pantothenate, and acetamide.

\section{DISCUSSION}

It appears from the preceding that there is no justification for maintaining $P$. gladioli and $P$. marginata as separate species. The differences originally noted between these species do not appear substantiated. Our tests of $P$. marginata ATCC 10248 indicate that its properties are identical to those described for $P$. gladioli. Consequently, the few differences which were reported between these species (Table 1) were apparently due to the use of different techniques and media, such as that used for pigment formation, and to problems of interpretation, such as with indole formation and presence of capsules. Likewise, the description of the diseases caused by the two pathogens are so similar that it is evident that moderate changes in environmental conditions could account for the differences noted. This leaves the question of which species name should be recognized. The original description of both organisms are of equal quality, and consequently it can be argued that the name $P$. gladioli should be used since it was described first and has priority. On the other hand, there are no surviving cultures of $P$. gladioli, and there has been no work conducted with it in contrast to $P$. marginata. Nevertheless, it is our recommendation that $P$. gladioli be the recognized name and that $P$. marginata be considered a later synonym of $P$. gladioli. The reasons for this recommendation are as follows: (i) priority of $P$. gladioli as previously noted; (ii) the confusion surrounding the description of $P$. marginata with regard to pigment formation. Evidence of this confusion can be seen from the fact that both fluorescent and nonfluorescent organisms are included in culture collections as $P$. marginata (14), and (iii) the similarity of the name $P$. marginata to that of $P$. marginalis, which also could lead to some confusion. We further propose that the strain previously described and designated (1) as the "lectotype" strain of $P$. marginata (ATCC 10248, NCPPB 1891) be designated as the neotype strain of $P$. gladioli.

\section{REPRINT REQUESTS}

Address reprint requests to: Dr. D. C. Hildebrand, Department of Plant Pathology, University of California, Berkeley, Calif. 94720.

\section{LITERATURE CITED}

1. Ballard, R. W., N. J. Palleroni, M. Doudoroff, R. Y. Stanier, and M. Mandel. 1970. Taxonomy of the aerobic pseudomonads: Pseudomonas cepacia, $P$. marginata, $P$. alliicola, and $P$. caryophylli. J. Gen. Microbiol. 60:199-214.

2. Bergey, D. H., R. S. Breed, E. G. D. Murray, and A. P. Hitchens. 1939. Bergey's manual of determinative bacteriology, 5 th ed. The Williams \& Wilkins Co., Baltimore.

3. Bergey, D. H., F. C. Harrison, R. S. Breed, B. W. Hammer, and F. M. Huntoon. 1930. Bergey's 
manual of determinative bacteriology, $3 \mathrm{rd}$ ed. The Williams \& Wilkins Co., Baltimore.

4. Breed, R. S., E. G. D. Murray, and N. R. Smith. 1957. Bergey's manual of determinative bacteriology, 7th ed. The Williams \& Wilkins Co., Baltimore.

5. Bryan, M. K. 1927. Beef infusion versus beef extract media. Phytopathology 17:413-414.

6. Burkholder, W. H. 1942. Three bacterial plant pathogens: Phytomonas caryophylli sp.n., Phytomonas alliicola sp.n., and Phytomonas manihotis (Arthaud-Berthet et Bondar) Viegas. Phytopathology 32:141-149.

7. Elliott, C. 1930. Manual of bacterial plant pathogens. The Williams \& Wilkins Co., Baltimore.

8. Elliott, C. 1951. Manual of bacterial plant pathogens, 2nd ed. Chronica Botanica, Waltham, Mass.

9. Hildebrand, D. C. 1971. Pectate and pectin gels for differentiation of Pseudomonas sp. and other bacterial plant pathogens. Phytopathology 61:1430-1436.

10. King, E. O., M. K. Ward, and D. E. Raney. 1954. Two simple media for the demonstration of pyocyanin and fluorescein. J. Lab. Clin. Med. 44:301-307.

11. McCulloch, L. 1921. A bacterial disease of gladiolus. Science 54:115-116.

12. McCulloch, L. 1924. A leaf and corm disease of gladioli caused by Bacterium narginatum. J. Agr. Res. 29:159-177.

13. McCulloch, L. 1947. Notes on a brown pigment and other unusual characters in cultures of Bacterium marginatum. Phytopathology 37:349-353.

14. Sands, D. C., M. N. Schroth, and D. C. Hildebrand. 1970. Taxonomy of phytopathogenic pseudomonads. J. Bacteriol. 101:9-23.

15. Severini, G. 1913. Una bacteriosi dell'Ixia maculata e del Gladiolus Colvilli. Ann. Bot. (Rome) 11:413-424.

16. Severini, G. 1913. Inttorno alle attivita enzimatiche di due bacteri patogeni per le piante. Ann. Bot. (Rome) 11:441-452.

17. Society of American Bacteriologists. 1967. Manual of Microbiological Methods, p. 315. McGraw-Hill Book Co., Inc., New York.

18. Stapp, C. 1928. Schizomycetes (Spaltpilze oder Bakterien). In Paul Sorauer, (ed.), Handb. PflKrankh. 5, Aufl. 2,1, Berlin.

19. Stapp, C. 1956. Bakterielle Krankheiten. In Paul Sorauer, (ed.), Handb. PflKrankh. II, Aufl. 6,2; Berlin.

20. Starr, M. P., and W. H. Burkholder. 1942. Lipolytic activity of phytopathogenic bacteria determined by means of spirit blue agar and its taxonomic significance. Phytopathology 32:598-604. 